Article

\title{
Size-Dependent Antibacterial Activity of Silver Nanoparticle-Loaded Graphene Oxide Nanosheets
}

\author{
Thi Tuong Vi Truong ${ }^{1}$, Selvaraj Rajesh Kumar ${ }^{1}{ }^{1}$, Yu-Tzu Huang ${ }^{2}$, Dave W. Chen ${ }^{3}$, \\ Yu-Kuo Liu ${ }^{1}$ and Shingjiang Jessie Lue ${ }^{1,3,4, *(D)}$ \\ 1 Department of Chemical and Materials Engineering, Chang Gung University, Taoyuan City 33302, Taiwan; \\ truongthituongvi005@gmail.com (T.T.V.T.); rajeshkumarnst@gmail.com (S.R.K.); \\ ykliu@mail.cgu.edu.tw (Y.-K.L.) \\ 2 Department of Chemical Engineering, Chung Yuan Christian University, Taoyuan City 32023, Taiwan; \\ yt_huang@cycu.edu.tw \\ 3 Department of Orthopedic Surgery, Chang Gung Memorial Hospital, Keelung City 20445, Taiwan; \\ mr5181@cgmh.org.tw \\ 4 Department of Safety, Health and Environment Engineering, Ming-Chi University of Technology, \\ New Taipei City 24301, Taiwan \\ * Correspondence: jessie@mail.cgu.edu.tw; Tel.: +866-3-211-8800 (ext. 5489); Fax: +886-3-211-8700
}

Received: 5 May 2020; Accepted: 14 June 2020; Published: 20 June 2020

\begin{abstract}
A series of graphene oxide (GO) suspensions with different particle sizes $(<100 \mathrm{~nm}$, $\sim 100 \mathrm{~nm}, \sim 1 \mu \mathrm{m}$ and $>1 \mu \mathrm{m}$ ) were successfully fabricated after $0,30,60$ and $120 \mathrm{~min}$ of sonication, respectively. The antibacterial properties of GO suspensions showed that $>1 \mu \mathrm{m}$ GO size resulted in a loss of nearly $50 \%$ of bacterial viability, which was higher than treatment by $\sim 100 \mathrm{~nm}$ GO size $(25 \%)$ towards Escherichia coli (E. coli). Complete entrapment of bacteria by the larger GO was observed in transmission electron microscopy (TEM). Silver nanoparticles (Ag NPs) were doped onto GO samples with different lateral sizes to form GO-Ag NP composites. Resulting larger GO-Ag NPs showed higher antibacterial activity than smaller GO-Ag NPs. As observed by Fourier transform infrared spectroscopy (FTIR), the interaction between E. coli and GO occurred mainly at the outer membrane, where membrane amino acids interact with hydroxyl and epoxy groups. The reactive oxygen species (ROS) and the considerable penetration of released $\mathrm{Ag}^{+}$into the inner bacterial cell membrane result in loss of membrane integrity and damaged morphology. The present work improves the combined action of GO size effect with constant Ag loadings for potential antibacterial activity.
\end{abstract}

Keywords: graphene oxide; silver nanoparticles; size effect; antibacterial activity; reactive oxygen species

\section{Introduction}

To date, the rapid development of bacterial infections has threatened health and life. However, antibiotic resistance is making some infections extremely difficult to treat [1]. This issue has resulted in an urgent demand for advanced nanomaterials [2,3]. To overcome this problem, several replacement materials for antibacterial treatment such as carbonaceous nanomaterials [4], metal nanoparticles and metal oxide nanoparticles [5] have been explored.

Graphene oxide (GO) is composed of single-atom-thick sheets of $\mathrm{sp}^{2}$-bonded carbon with oxygen-containing functional groups. It is a typical two-dimensional material made of carbon atoms in a honeycomb crystal lattice [6] and can be modified into various derivatives and composites [7]. GO is considered to be a "nanoknife" whose sharp edge can "cut" bacterial membrane to cause cell damage [8]. Mangadlao et al. reported on how the sharp edges of processed GO sheets can immobilize 
bacteria onto the GO sheet surface, preventing it from puncturing and developing [9]. Zhou et al. proved that the wrinkled surface of GO sheets contributed to the bactericidal effect [10]. In addition, GO exhibited antibacterial activity via chemical factors. For instance, Liu et al. proposed that GO can cause stress to bacterial membranes by oxidizing the cellular membrane structure [11]. Moreover, Kurantowicz et al. showed that GO can cause mechanical stress by direct attachment to the surface of bacteria [12]. Thereby, the functional groups of GO, including carboxyl groups (-COOH), epoxy groups (-C-O-C) which possibly bonded to, and consumed, bacteria [13].

The mechanism of GO antibacterial activity is still being explored. One noticeable issue with using GO in biological research is the particle size factor. Liu et al. reported that in the suspension phase, larger GO sheets $\left(0.75 \mu \mathrm{m}^{2}\right)$ completely covered E. coli, resulting in much greater loss of bacterial viability than smaller GO sheets $\left(0.01 \mu \mathrm{m}^{2}\right)$ [14]. Zhao et al. showed that larger GO sheets $(0.5$ to $3 \mu \mathrm{m})$ caused higher antibacterial activity. They showed scanning emission microscopy (SEM) images of E. coli membrane rupture and dispersion of the cytoplasm into the extracellular surroundings after exposure to large GO sheets [15]. Perreault et al. proved that large GO sheets exhibited higher antibacterial activity due to bacterial entrapment and inhibition of cell proliferation. Faria et al. prepared small-size debris GO, which showed a lower antibacterial effect than that of original-size GO. They proved that the loss of glutathione was lower when GO was fragmented into debris phase [16]. On the other hand, Jia et al. proved that small GO sheets exhibited higher antimicrobial activity towards Tox2 bacteria than large GO sheets due to the induction of cytotoxicity via internalization [17].

In the GO-coated membrane phase, small GO sheets approximately $0.01 \mu \mathrm{m}^{2}$ in size exhibited a more effective antimicrobial effect on E. coli than large GO sheets approximately $0.65 \mu \mathrm{m}^{2}$ in size. One possible reason is that small GO sheets possess a higher defect density, which facilitates interactions between GO functional groups and bacterial membranes, leading to more bacterial death [18]. In addition, Dallavalle et al. hypothesized that the small GO sheets can pierce the membrane in a suitable geometric orientation, which was reproduced by computational studies [19]. In light of the inconsistent results of the GO size-dependent bactericidal effect, further study to investigate the size-dependent properties is needed.

Modification of GO with nanomaterials enhances its antibacterial performance [20-22]. In particular, silver nanoparticles (Ag NPs) are among the effective novel metals in biomedical applications. Silver nanoparticles are well-known materials for good antibacterial activity behavior even at small concentrations [23]. Previous studies have demonstrated that the GO-Ag NP antibacterial activity benefits from the synergetic effects between GO and Ag NPs [24,25]. In the GO-Ag NPs, GO wraps the bacterial surface while Ag NPs penetrate into the inner cell or accumulate at the bacterial membrane, destroying the bacterial cells. The GO-Ag NPs synergistic effect was examined using a wide range of bacteria including gram-negative and gram-positive bacteria such as Staphylococcus aureus [24], Pseudomonas aeruginosa [26], Bacillus subtilis [27], Klebsiella pneumonia [28], etc. However, to the best of our knowledge, no research data regarding the antibacterial activity of GO sheets with different lateral sizes in GO-Ag NP composites have been reported yet.

To influence the GO size effects, we incorporate the constant loading of Ag NPs into different-sized GO nanosheets. Transmission electron microscope (TEM), dynamic light scattering (DLS) and inductively coupled plasma-optical emission spectrometry (ICP-OES) were the main techniques used to characterize the GO and GO-Ag NPs. Subsequently, time-dependent antibacterial activity and live/dead cell assays were used to compare the size-dependent bactericidal activity. Reactive oxygen species (ROS) assays, TEM and Fourier transform infrared spectroscopy (FTIR) of GO- and GO-Ag NP-treated E. coli were applied to determine the reasons for the above findings. Finally, we propose insight into the bactericidal mechanisms on different GO sizes for GO and GO-Ag NP functionality. 


\section{Materials and Methods}

\subsection{Materials}

Graphite powder $(\mathrm{G})$, potassium permanganate $\left(\mathrm{KMnO}_{4}\right)$, hydrogen peroxide $\left(\mathrm{H}_{2} \mathrm{O}_{2}\right)$, potassium bromide (KBr), hoechst 333242 (HS), glutaraldehyde $50 \%$, sodium borohydride $\left(\mathrm{NaBH}_{4}\right), 1 \%$ osmic acid, 2' ',7'-dichlorodihydrofluorescein diacetate (DCFH-DA), propidium iodide (PI), dimethyl sulfoxide (DMSO) and silver nitrate $\left(\mathrm{AgNO}_{3}\right)$ were purchased from Sigma-Aldrich, St. Louis, MO, USA. Sulfuric acid $\left(\mathrm{H}_{2} \mathrm{SO}_{4}, 98 \%\right)$ was purchased from Lab Alley, Austin, Texas, USA. Hydrochloric acid ( $\left.\mathrm{HCl}\right)$ and nitric acid $\left(\mathrm{HNO}_{3}\right)$ were purchased from Showa Chemical Industry Co., Ltd., Honshu, Japan. Luria-Bertani (LB) broth, phosphate-buffered saline (PBS) and agar-agar powder were purchased from Sigma-Aldrich, St. Louis, MO, USA. E. coli (DH5 $\alpha$ ) was purchased from Thermo Fisher Scientific Inc., Taipei City, Taiwan.

\subsection{Synthesis of $G O$}

GO was fabricated according to the modified Hummer's method with trivial modification [29]. Briefly, $3 \mathrm{~g}$ of graphite powder was dispersed in $400 \mathrm{~mL}$ of $\mathrm{H}_{2} \mathrm{SO}_{4}$ solution with continuous stirring for $10 \mathrm{~min}$. Then, $3 \mathrm{~g}$ of $\mathrm{KMnO}_{4}$ was added. A total of five portions of $\mathrm{KMnO}_{4}$ were sequentially added once the solution changed from green to black. Subsequently, $500 \mathrm{~g}$ of deionized (DI) water was added to avoid increasing the temperature. The supernatant solution was discarded, and the residual gel-like products were washed with $\mathrm{HCl}$ and DI water using Benchtop centrifugation (Hermel Z236K, Sanchong, New Taipei City, Taiwan) under 10,000 rpm until a neutral $\mathrm{pH}$ was obtained. The final products were dried overnight in a vacuum oven at $60^{\circ} \mathrm{C}$.

\subsection{Synthesis of GO with Different Lateral Sizes}

Four batches of GO suspensions were prepared for various GO sizes. Each batch contained $1 \mathrm{mg}$ $\mathrm{mL}^{-1}$ GO powder. The GO suspensions were sonicated for different times: 0, 30, 60 and 120 min using a probe sonicator Qsonica (Sunway Scientific Corporation, Hsinchu, Taiwan). An ice bath was used during the sonication process. The final GO products were kept in dry, cool areas for further analysis.

\subsection{Synthesis of GO-Ag NPs with Different Latteral Sizes of GO}

In short, $5 \mathrm{~mL}$ of GO solution at a concentration of $1 \mathrm{mg} \mathrm{mL}^{-1}$ was mixed with $15 \mathrm{~mL}$ of $1 \times 10^{-3}$ $\mathrm{M} \mathrm{AgNO}_{3}$ for $30 \mathrm{~min}$. Subsequently, $5 \mathrm{~mL}$ of a $3.35 \times 10^{-3} \mathrm{M} \mathrm{NaBH}_{4}$ aqueous solution was added dropwise and continuously stirred for $1 \mathrm{~h}$ in an ice bath. The color of the solution slowly turned dark yellow, indicating the reduction in $\mathrm{Ag}^{+}$ions and the formation of Ag NPs. The synthesized GO-Ag NP composites were washed many times with DI water via centrifugation at 10,000 rpm for $10 \mathrm{~min}$. Final products were dialyzed using dialysis 2000 Da to remove unreacted Ag solution and/or Ag particles for 1 day before further analysis.

\subsection{Characterizations}

Two-dimensional GO and GO-Ag NP images were obtained using TEM (JEM 2000EXII, JEOL, Tokyo, Japan). Sample structures were analyzed using X-ray diffraction (XRD, Siemens D5005, Oslo, Norway) to determine the element structure and phase purity. The $2 \theta$ diffractogram was scanned in the range of $5-80^{\circ}$ at a scan rate of $4^{\circ} \mathrm{min}^{-1}$ with $\mathrm{Cu}-\mathrm{K} \alpha$ radiation. FTIR (Horiba FT-730G, Kyoto, Japan) was used to identify the functional groups of the sample in the range of $500-4000 \mathrm{~cm}^{-1}$. A UV-visible spectrophotometer (V-650, Tokyo, Japan) was used to measure the change in the lateral size of GO and GO-Ag NP with various absorption wavelengths. The zeta potential and size distribution of GO and GO-Ag NPs were recorded in triplicate via a light scattering instrument (Zetasizer, 2000 HAS, Malvern, Worcestershire, UK). The Ag content was analyzed using inductively coupled plasma optical emission spectrometry (ICP-OES, Agilent 700 Series ICP Optical Emission Spectrometers, Victoria, Australia). 


\subsection{Antibacterial Test}

\subsubsection{Time-Dependent Antibacterial Activity Assay}

Optimal readings were taken to examine the bacterial growth when GO or GO-Ag NPs was presented. The GO suspensions were stable up to $13 \mathrm{~h}$. Before the antibacterial experiments, E. coli colonies were cultured overnight in LB broth at $37^{\circ} \mathrm{C}$ using an orbital shaker incubator (Firstek S300R Datong, Taipei City, Taiwan) and gently centrifuged at $2000 \mathrm{rpm}$ for $5 \mathrm{~min}$ using a benchtop centrifuge. The supernatant was removed. The precipitate was collected and then diluted with LB broth to achieve an optical density of 0.3 . The above bacterial suspensions were then transferred into 48 -well plates. Approximately $50 \mu \mathrm{L}$ of each sample suspension was added to $450 \mu \mathrm{L}$ of LB broth, and the plates were shaken for $1 \mathrm{~h}$. Pristine LB broth without treatment was used as a control sample. Ten microliters of the sample mixture was removed and transferred into 96-well plates. Subsequently, $90 \mu \mathrm{L}$ LB broth was added to each well. Triplicate optical density readings were measured using a microplate reader (Biotek, Hong Kong, China) at a wavelength of $600 \mathrm{~nm}$. Data were read at intervals until $13 \mathrm{~h}$ for GO and $4 \mathrm{~h}$ for GO-Ag NP samples. The inhibition percentage was calculated via the following equation:

$$
\text { Inhibition }(\%)=\left(1-\frac{O D \text { value of sample at time } t-O D \text { value of sample at time } 0}{\text { OD value of control at time } t-O D \text { value of control at time } 0}\right) \times 100
$$

\subsubsection{Bacterial Morphology of GO and GO-Ag NP Treatments}

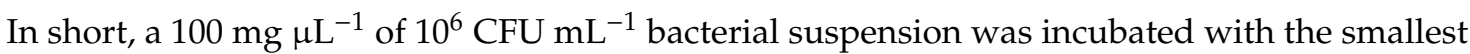
and largest GO sheets for $1 \mathrm{~h}$. The mixture was fixed with $4 \%$ glutaraldehyde for $1 \mathrm{~h}$ and washed twice with PBS. The bacterial suspension was postfixed with $1 \%$ osmic acid for $45 \mathrm{~min}$ and washed twice with PBS. The samples were dehydrated with gradient ethanol (20\%, 40\%, 60\%, 80\%). The samples were then dropped on a gold grid for TEM observation.

\subsubsection{Live/Dead Cell Assay}

The E. coli suspensions were diluted with PBS solution (to achieve an OD value close to 0.1) before treatment with the smallest and largest GO sheets $\left(100 \mu \mathrm{g} \mathrm{mL}{ }^{-1}\right)$ for $2 \mathrm{~h}$ of incubation. A mixture containing $5 \mu \mathrm{L}$ of HS and $1 \mu \mathrm{L}$ of PI was added to the bacterial suspension. These mixtures were then incubated for 15 min in the dark and washed twice with PBS solution. A confocal laser scanning microscope (CLSM, Zeiss LSM 510-Meta, Heidelberg, Germany) was used to observe the live/dead cells.

\subsubsection{Reactive Oxygen Species}

Theoretically, the intracellular ROS was measured based on the intracellular peroxide-dependent oxidation of $2^{\prime}, 7^{\prime}$-dichlorodihydrofluorescein diacetate (DCFH-DA) to form the fluorescent compound $2^{\prime}, 7^{\prime}$-dichlorofluorescein (DCF) [30]. Once materials have high ROS production, the green color was detected. Therefore, DCFH-DA assay was used in this study. A DCFH-DA stock solution was prepared in DMSO solution. E. coli suspensions with an OD close to 0.1 were treated with $100 \mu \mathrm{g} \mathrm{mL}-1$ control, GO and GO-Ag NP solutions with the smallest and largest lateral sizes for $2 \mathrm{~h}$ of incubation. The mixture was added to $100 \mu \mathrm{L}$ of $25 \mu \mathrm{M}$ DCFH-DA without shaking. Those mixtures were kept in the dark for $30 \mathrm{~min}$ at $37^{\circ} \mathrm{C}$. The samples were washed twice using PBS. Fluorescence images were obtained using a CLSM at an emission of $535 \mathrm{~nm}$ and excitation of $485 \mathrm{~nm}$. The ROS level was evaluated by green color production.

\section{Results}

\subsection{Characterization of GO with Different Sizes}

The preparation process is illustrated in Figure 1. After sonication, the size of GO can be categorized as very large (original size) $(>1 \mu \mathrm{m})$, moderate $(\sim 1 \mu \mathrm{m})$, small $(<1 \mu \mathrm{m})$ and ultrasmall 
$(\sim 100 \mathrm{~nm})$. The size was determined by a DLS analyzer (Table 1$)$. The size variation of GO was clearly observed under TEM (Figure 2a-d). The size determined by DLS might be larger than that calculated by TEM. This is probably attributed to the fact that GO has a non-spherical shape and extends in various directions. The DLS measurement assumes the particles are spherical in shape. This instrument may not be able to detect small particles below the detection limit. In theory, the light scattered by a particle depends upon the shape, size and molecular weight, as well as the refractive indices, of the particle. The scattered light from individual particles is interrupted by the scattered light from other particles before reaching the detector, since the molecules are in random movement due to Brownian motion, which will result in random fluctuations in time [31]. DLS data usually exhibited larger values than TEM due to the movement of the nanoparticles when they were dispersed in solution [32]. Although the DLS and TEM analyses showed different size values, the data were positively correlated.

Figure 3 shows the UV-visible spectrum of GO with different lateral sizes. The GO spectrum has a typical shoulder and main peak: a shoulder peak attributed to $\pi-\pi *$ bonding and attributed to $n-\pi$ * bonding. When GO was subjected to ultrasonication, the additional oxygen between GO layers made it easier to exfoliate; therefore, the smaller GO had a higher intensity value than the larger GO. This result was consistent with a previous report [33].

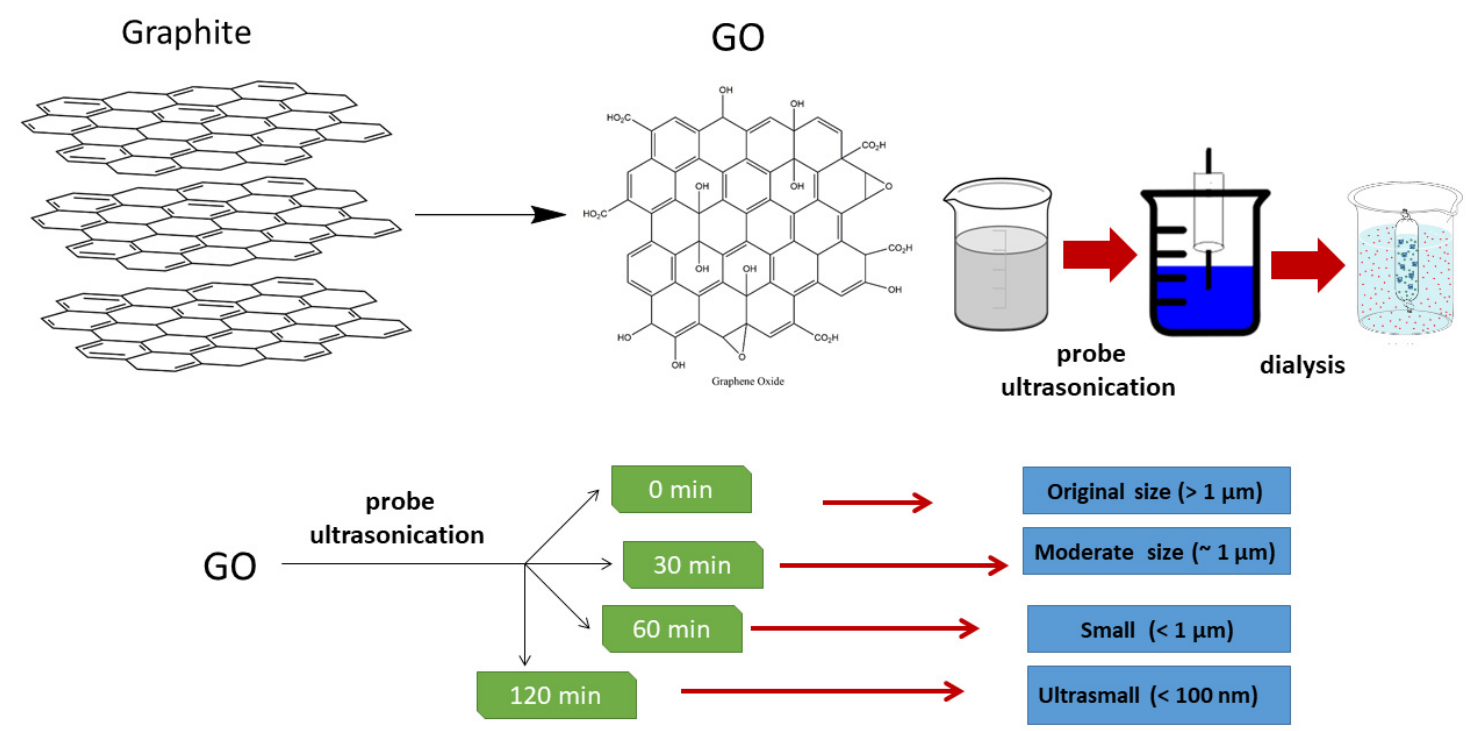

Figure 1. Preparation of GO from graphite and manufacturing of different GO sizes via probe sonication.

Table 1. Nanomaterial size and $\zeta$-potential of graphene oxide (GO) with different sizes in aqueous solution (transmission electron microscopy (TEM) images were calculated for 50 pieces of GO sheets for each batch).

\begin{tabular}{|c|c|c|c|c|}
\hline GO & $\sim 100 \mathrm{~nm}$ & $100 \mathrm{~nm} \sim 1 \mu \mathrm{m}$ & $\sim 1 \mu \mathrm{m}$ & $>1 \mu \mathrm{m}$ \\
\hline DLS hydrodynamic size (nm) & $140.8 \pm 8.8$ & $320.6 \pm 71.6$ & $1098.7 \pm 381.7$ & $4605.3 \pm 338.8$ \\
\hline TEM results $(\mathrm{nm})$ & $69.0 \pm 7.8$ & $161.4 \pm 44.1$ & $1005.2 \pm 378.9$ & $4340.1 \pm 1189.1$ \\
\hline$\zeta$-potential $(\mathrm{mV})$ & $-35.1 \pm 2.2$ & $-36.7 \pm 10.2$ & $-33.1 \pm 2.2$ & $-36.7 \pm 5.3$ \\
\hline
\end{tabular}



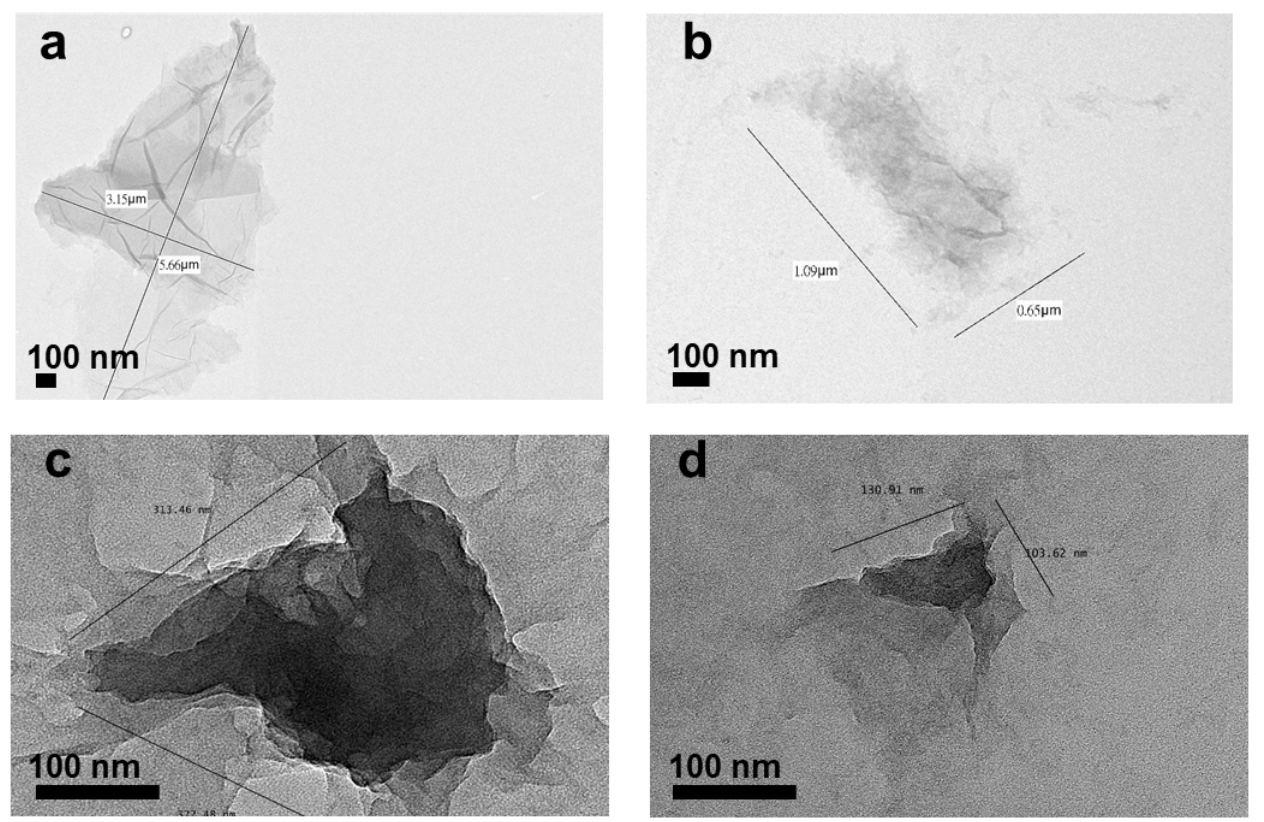

Figure 2. TEM images of GO samples with various sizes: (a) $>1 \mu \mathrm{m},(\mathbf{b}) \sim 1 \mu \mathrm{m},(\mathbf{c}) 100 \mathrm{~nm}$ to $1 \mu \mathrm{m}$ and (d) $\sim 100 \mathrm{~nm}$.

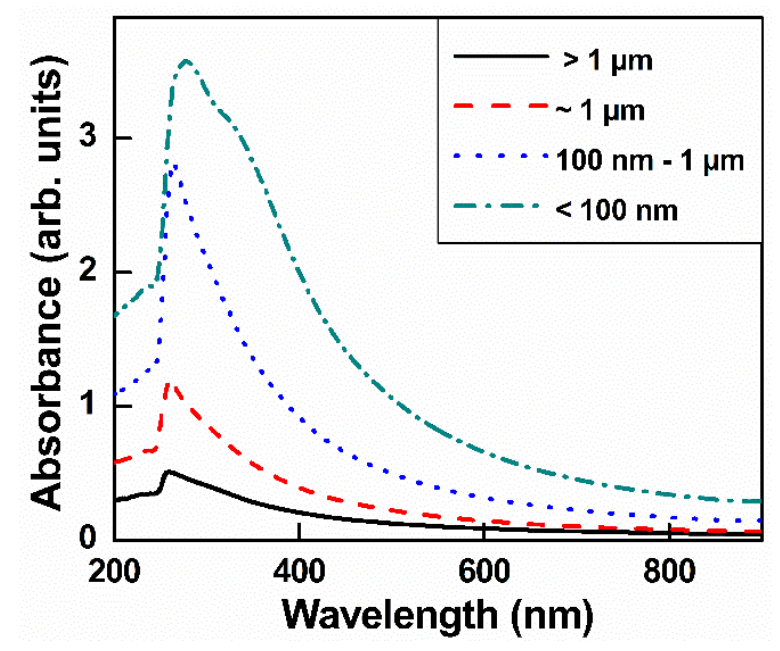

Figure 3. UV-visible spectra of GO with different sizes in aqueous solution.

As shown in Figure S1a, the FTIR results have proven the characteristics of GO domain groups [29]. The GO spectrum showed characteristic peaks at $3404(\mathrm{C}-\mathrm{OH}), 1733(\mathrm{C}=\mathrm{O}), 1622$ (the vibration of $\mathrm{C}=\mathrm{C}$ domains), $1220(\mathrm{C}-\mathrm{O})$ and $1055 \mathrm{~cm}^{-1}$ ( $\mathrm{C}-\mathrm{O}$ stretching). Based on the presence of these oxygen-containing groups, it was confirmed that these groups resulted from the GO oxidation process. This FTIR result is similar to that of a previous study [34]. Moreover, the XRD pattern showed a typical peak at $11.7^{\circ}$ (Figure $\mathrm{S1b}$ ), indicating that GO was successfully prepared. The zeta potential of GO of various sizes did not fluctuate much $(-30 \sim-37 \mathrm{mV}$, Table 1$)$, which indicated that GO remains moderately stable after the sonication process. The negative zeta potential values originated from the carboxylate functional groups in GO and were not size-dependent.

\subsection{Characterizations of GO-Ag NPs Corresponding to Different Sizes of GO}

GO-Ag NPs with different GO sizes were fabricated using $\mathrm{NaBH}_{4}$ as both a stabilizer and a reduction agent. TEM images of GO-Ag NPs with different sizes of GO are shown in Figure 4a-d. Obviously, the Ag NPs were uniformly anchored on the GO layers, regardless of the GO size. The UV 
spectra of the GO-Ag NP samples showed two main peaks, $230 \mathrm{~nm}$ attributed to GO and $400 \mathrm{~nm}$ attributed to Ag NPs [35] (Figure 5). Obviously, the peak intensity at $230 \mathrm{~nm}$ for the smaller GO-Ag NPs was higher than that for the larger GO-Ag NPs. The trend is similar to that in GO solutions (Figure 3).
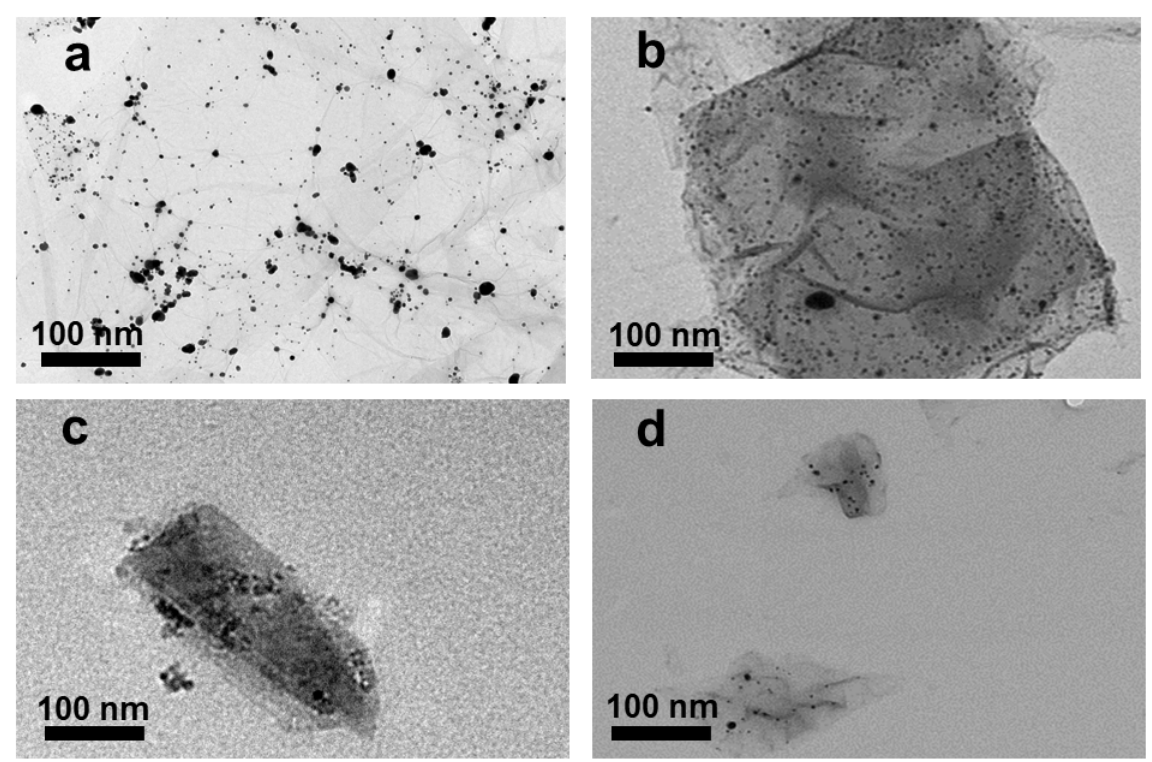

Figure 4. TEM images of GO-Ag NPs with various GO sizes (a) $>1 \mu \mathrm{m},(\mathbf{b}) \sim 1 \mu \mathrm{m}$, (c) $100 \mathrm{~nm}$ to $1 \mu \mathrm{m}$ and $(\mathbf{d}) \sim 100 \mathrm{~nm}$.

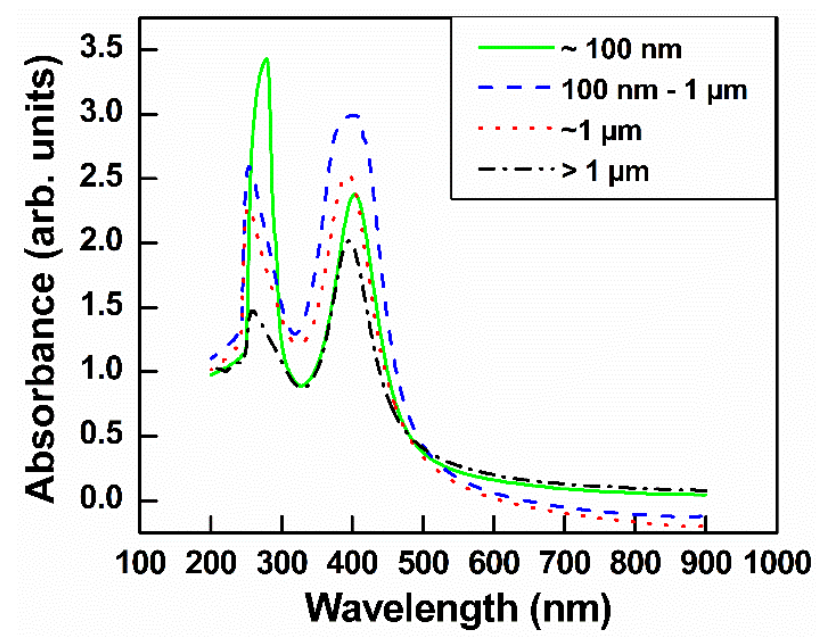

Figure 5. UV-visible spectra of GO-Ag NPs with various sizes GO.

The characterization of GO-Ag NPs using FTIR and XRD is shown in Figure S2. According to Figure S2a, FTIR analysis showed that the intensities of GO characteristic peaks significantly decreased. This result suggested that the hydroxyl groups in GO may react with $\mathrm{Ag}$ [36]. The grafting of $\mathrm{Ag}$ NPs onto GO sheets was also analyzed using XRD analysis. According to Figure S2b, the GO-Ag $\mathrm{NP}$ composite gave rise to the main XRD peaks at $38.1^{\circ}, 44.3^{\circ}, 64.5^{\circ}$, and $77.5^{\circ}$, corresponding to the (111), (200), (220), and (311) planes, respectively and confirming the face-centered cubic structure of Ag. However, the main peak of GO $\left(2 \theta\right.$ of $\left.10^{\circ}\right)$ disappeared in the spectra of the GO-Ag NP samples, probably due to the change in lattice position [37]. Hui et al. proved that the disappearance of GO peaks due to the incorporation of GO and Ag NPs worked as spacers, avoiding the restacking of GO layers $[38,39]$. Zhao et al. reported similar finding in layered graphite oxide preparation [40]. 
As indicated in Figure 6, the initial $\mathrm{Ag}^{+}$content in the largest GO-Ag NPs was approximately $400 \mathrm{ppb}$, higher than that in the smallest GO-Ag NPs (approximately $200 \mathrm{ppb}$ ). The $\mathrm{Ag}^{+}$content increased over time. On the 5th day, the $\mathrm{Ag}^{+}$content in small GO-Ag NPs reached 285 ppb and remained stable until the 10th day. On the other hand, $\mathrm{Ag}^{+}$in the largest GO-Ag NPs was released rapidly, and a maximum content of $688 \mathrm{ppb} \mathrm{Ag}^{+}$was achieved at day 10.

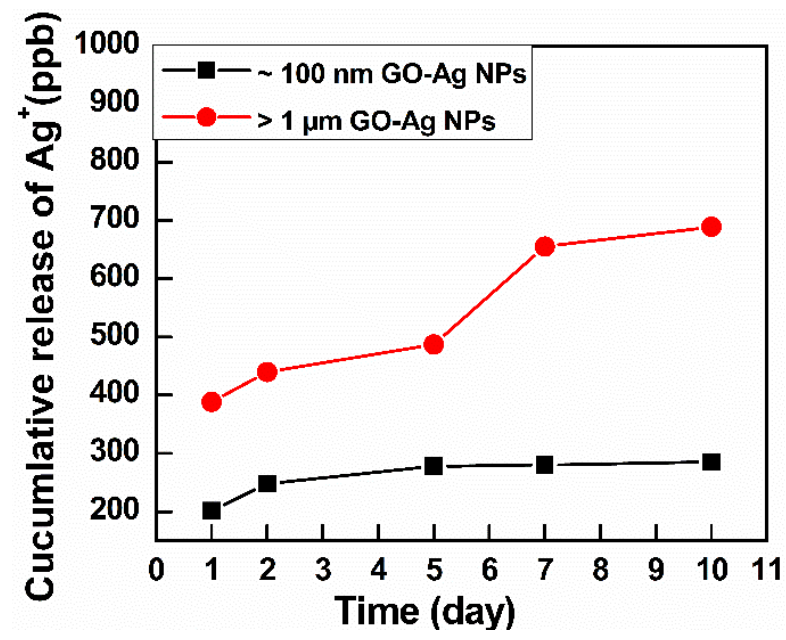

Figure 6. $\mathrm{Ag}^{+}$release analysis by ICP-EOS of GO-Ag NPs with GO sizes $>1 \mu \mathrm{m}$ and $\sim 100 \mathrm{~nm}$.

\subsection{Antibacterial Activity of GO with Different Sizes}

Initially, E. coli suspensions were cultured with LB broth until reaching log phase and were diluted to an OD value of approximately 0.15. Bacteria were treated with different GO sizes at the same concentration of $300 \mu \mathrm{g} \mathrm{mL}^{-1}$. The growth curves are shown in Figure S3a, and the calculated inhibition percentages are shown in Figure 7. According to Figure 7, the trend of inhibition percentage steadily increased from the smallest GO to the largest GO. The quantitative inhibition percentages after $13 \mathrm{~h}$ of treatment were $17.8 \%, 30.1 \%, 41.8 \%$ and $47.9 \%$ for $\sim 100 \mathrm{~nm}, 100 \mathrm{~nm}$ to $1 \mu \mathrm{m}, \sim 1 \mu \mathrm{m}$ and $>1 \mu \mathrm{m} \mathrm{GO}$, respectively. There is a significant difference between $>1 \mu \mathrm{m}$ and $100 \mathrm{~nm}$ GO in the above inhibition percentage, whereas the inhibition between $>1$ and $\sim 1 \mu \mathrm{m}$ is similar. Note that the size of E. coli was from 0.5 to $2 \mu \mathrm{m}$, so that the larger GO size totally trapped the entire E. coli cell, producing higher damage to E. coli.

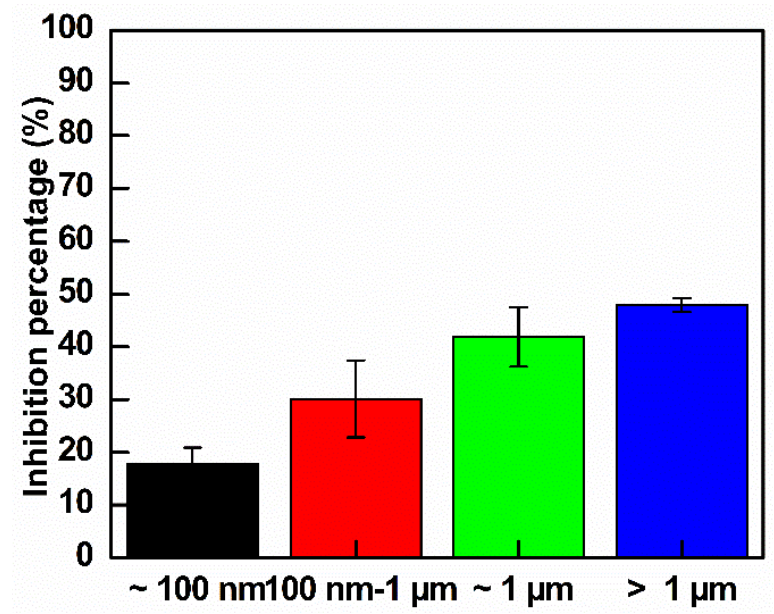

Figure 7. Inhibition rates of E. coli control and treated GO of different sizes after $13 \mathrm{~h}$ of observation $(n=3)$.

To evaluate the number of live/dead cells, fluorescence images were captured by CLSM using PI as the dead cell indicator and HS as the live cell indicator. As shown in Figure 8, the majority of bacteria 
in the control groups were still alive. After being exposed to small GO, some bacteria were damage, as showed in red color intensity increase. In the larger GO sample, there was a significant reduction in the extent of blue color in the images, whereas the extent of red color was increased. These results also confirmed that the antibacterial activity of the largest GO was higher than that of the smallest GO.

\section{PI (red) HS (green) Overlay}

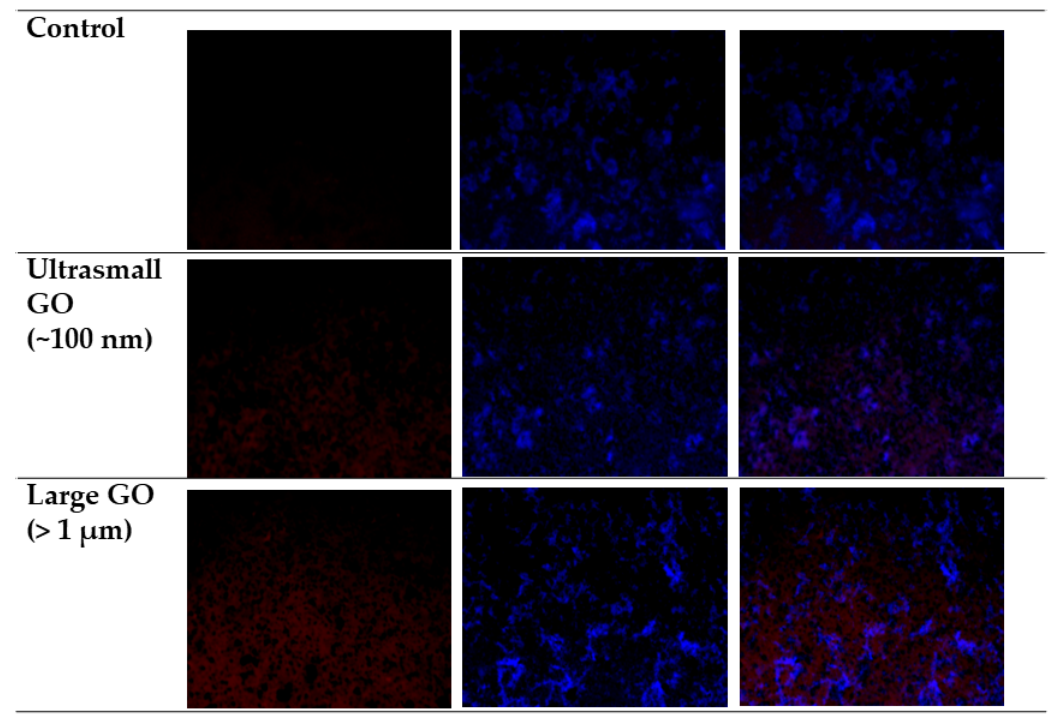

Figure 8. Live/dead cell staining by PI and HS of E. coli control culture and cultures subjected to treatments with $>1 \mu \mathrm{m}$ and $\sim 100 \mathrm{~nm}$ GO.

Under TEM analysis, the control E. coli appeared as typical smooth, rod-shape cells, as shown in Figure 9a. Obviously, E. coli cells were trapped by large GO (Figure 9b) and experienced serious damage. The $>1 \mu \mathrm{m}$ GO completely covered the E. coli cells, destroying the integrity of their morphology. This was because by entrapping the E. coli cells, the GO sheets isolated the E. coli colony from the nutrient medium and inhibited E. coli development. Liu et al. proved that the development of bacteria was restrained by a cell entrapment mechanism [11]. However, the $100 \mathrm{~nm}$ GO sheets were merely attached to the surrounding bacterial membrane (Figure 9c) by van der Waals forces between the $\mathrm{sp}^{2}$ interlayers in GO and the lipid bilayer of the bacterial cell membranes without stressing the whole E. coli cells (Figure 9c) [41]; therefore, the E. coli morphology after treatment with 100 nm GO sheets was not severely damaged.
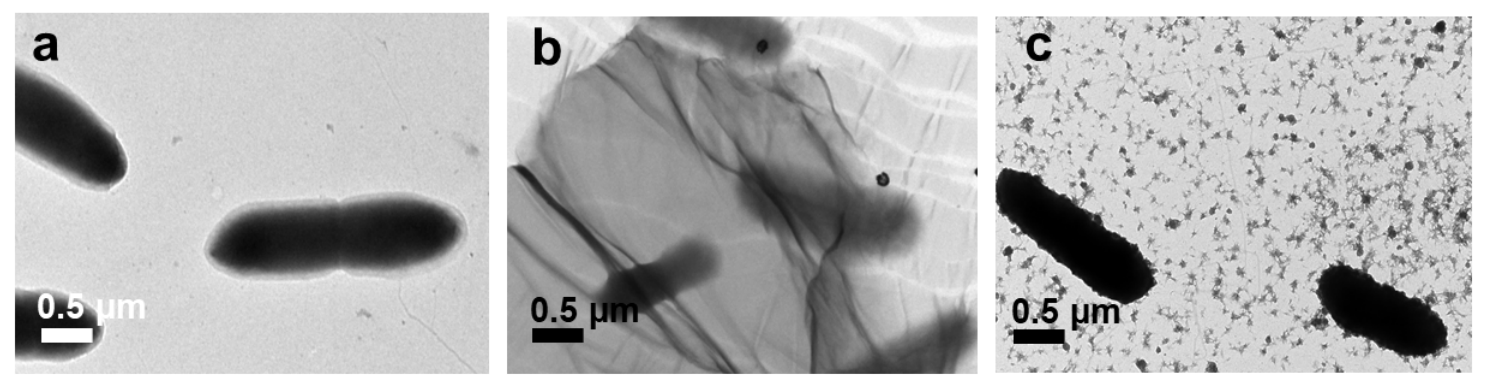

Figure 9. TEM images of the E. coli control cells (a) and cells treated with $>1 \mu \mathrm{m}(\mathbf{b})$ and $\sim 100 \mathrm{~nm}$ (c) GO.

DCFH-DA was used as an indicator for ROS detection. As shown in Figure 10a, the control sample was dark in color. GO with a size of $\sim 100 \mathrm{~nm}$ also showed no ROS signal (Figure 10b), whereas $>1 \mu \mathrm{m}$ GO exhibited weak green fluorescence, as indicated in Figure 10c. The low ROS production indicated 
that GO does not have a high impact on oxidative stress in E. coli. This result was in agreement with the results of Liu et al., who proved that the production of ROS induced by $>1 \mu \mathrm{m}$ GO was significantly higher than that induced by $\sim 100 \mathrm{~nm}$ GO [14]. In comparison, 100 nm GO sheets showed weaker antibacterial activity because they only adhered to the bacterial surface without efficiently isolating bacteria from the growth medium. Faria et al. prepared small-size debris GO, which showed lower antibacterial effects than that of original-size GO. They proved that the loss of glutathione was lower when GO was fragmented into debris phase [16].
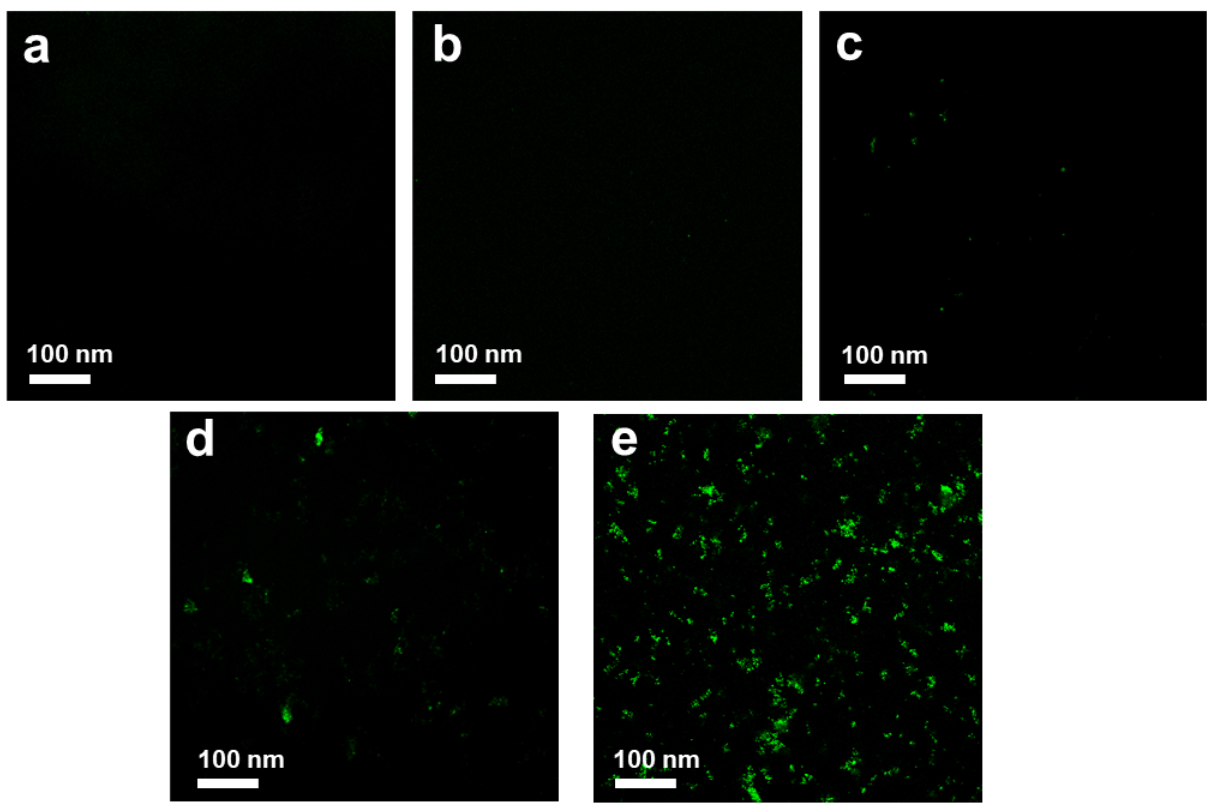

Figure 10. Reactive oxygen species (ROS) production of control (a), $100 \mathrm{~nm} \mathrm{GO}(\mathbf{b}),>1 \mu \mathrm{m} \mathrm{GO}$ (c), $\sim 100 \mathrm{~nm}$ GO-Ag NPs (d) and $>1 \mu \mathrm{m}$ GO-Ag NPs (e) at the same $2 \mathrm{~h}$ incubation time, the bacterial inhibition rates are $0.5 \%, 0.8 \%, 5.1 \%$ and $21.43 \%$ for samples $(\mathbf{b})-(\mathbf{e})$, respectively.

To investigate the bonding between bacteria after treatment with GO, FTIR spectroscopy was conducted. As shown in Figure 11, the peak at approximately $3413 \mathrm{~cm}^{-1}$ was ascribed to stretching of the $-\mathrm{NH}$ moiety of the amino acid after reacts with $-\mathrm{OH}$ in GO [42]. A significant peak at $1629 \mathrm{~cm}^{-1}$ was associated with secondary amides in the E. coli structure. On the other hand, the peaks at 1236 and $1409 \mathrm{~cm}^{-1}$ were attributed to the noncovalent bonding that occurred between $-\mathrm{COOH}$ and $-\mathrm{PO}_{4}^{-3}[43]$. The peak at $520 \mathrm{~cm}^{-1}$ was attributed to disulfide bonding (S-S) adherence between GO and E. coli after treatment, indicating that ions were formed in the outer membrane [44]. Therefore, the interaction of $>1 \mu \mathrm{m}$ and $\sim 100 \mathrm{~nm}$ GO with E. coli mainly occurred via GO's functional groups, wherein -OH and $-\mathrm{COOH}$ react with amino acids in the bacterial membrane. This research was in agreement with that of Efremova et al., who reported that GO sheets and E. coli cells interacted by means of a neutralization reaction between the bacterial membrane and functional group on the GO surface [45]. Camesano et al. proved that the adhesion between E. coli and GO arises from the negatively charged bacterial outer membrane and the deprotonated carboxylic acid groups on GO [46]. This noncovalent bonding interaction prevented the bacteria from accessing the nutrition medium; therefore, the membrane was physically damaged [41]. On the other hand, when E. coli was incubated with GO under shaking, the E. coli was cleaved by biochemical reaction. This may possibly place E. coli under stress or physical damage. Therefore, the antibacterial activity of $>1 \mu \mathrm{m}$ GO was significantly higher than that of $\sim 100 \mathrm{~nm} \mathrm{GO}$, and the proposed mechanism of GO antibacterial activity mainly involves physical wrapping, thus resulting in greater interaction with $E$. coli. 


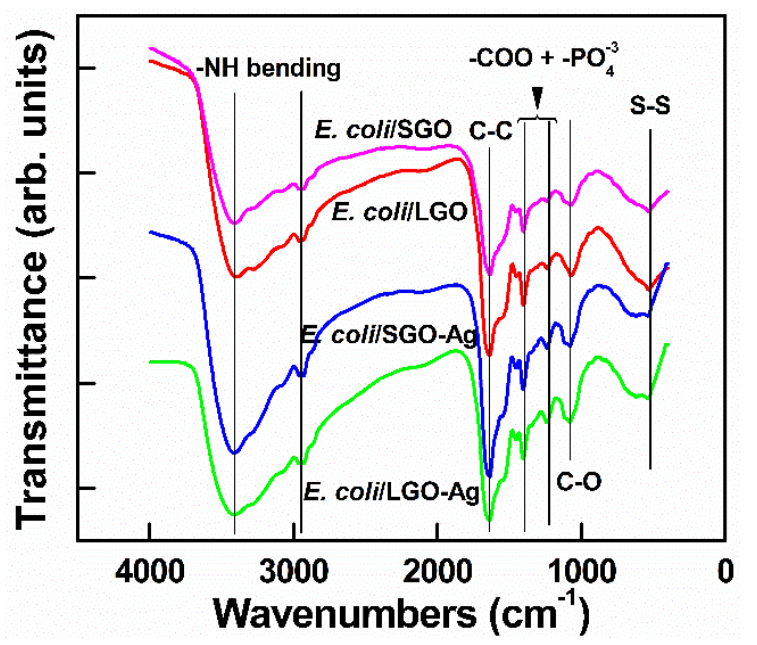

Figure 11. Fourier transform infrared spectroscopy (FTIR) characterizations of E. coli treated with $\sim 100$ $\mathrm{nm} \mathrm{GO},>1 \mu \mathrm{m} \mathrm{GO}, 100 \mathrm{~nm}$ GO-Ag NPs and >1 $\mu \mathrm{m}$ GO-Ag NPs.

\subsection{Antibacterial Activity of GO-Ag NPs with Different GO Sizes}

E. coli suspensions were cultured in LB broth until reaching log phase and were then diluted to an OD value of approximately 0.15 . The bacteria were treated with different sizes GO at the same concentration of $300 \mu \mathrm{g} \mathrm{mL} \mathrm{m}^{-1}$. The growth curve analysis was shown in Figure S3b and the calculated inhibition percentage was shown in Figure 12. As indicated in Figure 12, GO-Ag NPs larger than $100 \mathrm{~nm}$ exhibited good inhibition of $E$. coli. The quantitative inhibition percentages after $4 \mathrm{~h}$ of treatment were $27.6 \%, 80.6 \%, 83.2 \%$ and $88.6 \%$ for GO-Ag NPs $\sim 100 \mathrm{~nm}, 100 \mathrm{~nm}-1 \mu \mathrm{m}, \sim 1 \mu \mathrm{m}$ and $>1 \mu \mathrm{m}$, respectively. This study demonstrates a promising antibacterial effect of large GO-loaded Ag NPs. The largest GO-Ag NPs with a size of $>1 \mu \mathrm{m}$ had the greatest effect on the antibacterial activity.

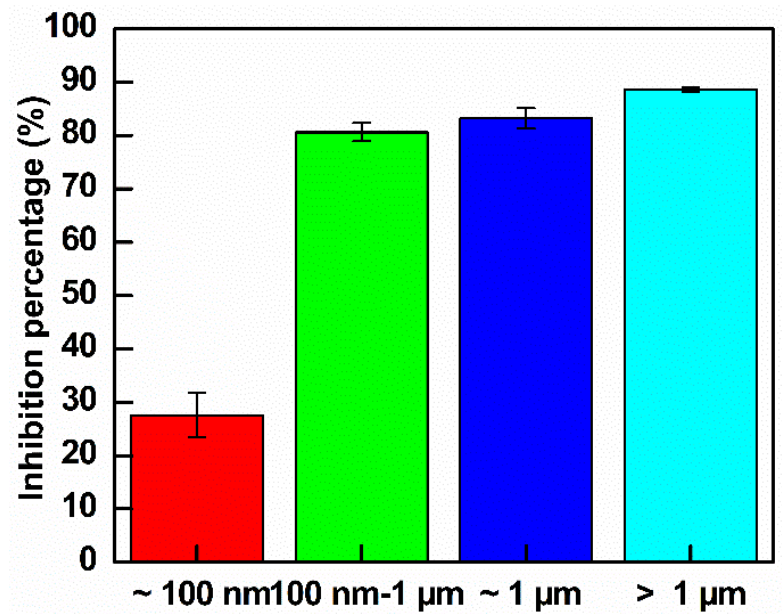

Figure 12. Inhibition rates of the control E. coli and treated E. coli with GO-Ag NPs with different GO sizes after $4 \mathrm{~h}$ of observation $(n=3)$.

Figure 10 shows that green fluorescence was clearly observed in E. coli treated with $100 \mathrm{~nm}$ GO-Ag NPs, indicating that small Ag NP-loaded GO produced a moderate level of ROS (Figure 10d). Noticeably, as shown in Figure 10e, a green color was detected, which indicated that the ROS level produced by $>1 \mu \mathrm{m}$ GO-Ag NPs may be one of the reasons for the antibacterial activity.

Subsequently, the FTIR results in Figure 11 show that after treatment of E. coli with $100 \mathrm{~nm}$ and $>1 \mu \mathrm{m}$ GO-Ag NPs, the spectral peaks were similar peaks to those of GO. However, the peaks at $520 \mathrm{~cm}^{-1}$ broadened and shifted to $620 \mathrm{~cm}^{-1}$, indicating that the metal interacted with the cell membrane [47]. 
In summary, the greater antibacterial activity of GO-Ag NPs with large GO sheets than of GO-Ag NPs with small GO sheets can be explained in three perspectives. At first, the large GO could enhance the binding between GO and the E. coli membrane, resulting in more interaction upon E. coli treatment with large GO. The binding interactions and destruction of E. coli treatment with large GO-Ag NPs involve penetration of Ag into the bacterial membrane, as indicated by the TEM image in Figure 13. As shown in Figure 13, after treatment with different sized GO-Ag NPs, the E. coli morphology exhibited integrity structure damage. In particular, E. coli after treatment with $>1 \mu \mathrm{m}$ (Figure 13a) and $\sim 1 \mu \mathrm{m}$ GO-Ag NPs (Figure 13b) becomes damaged, clustered and gathered together. The single E. coli found after treatment with $100 \mathrm{~nm}$ GO-Ag NPs (Figure 13c) did not show severe damage.
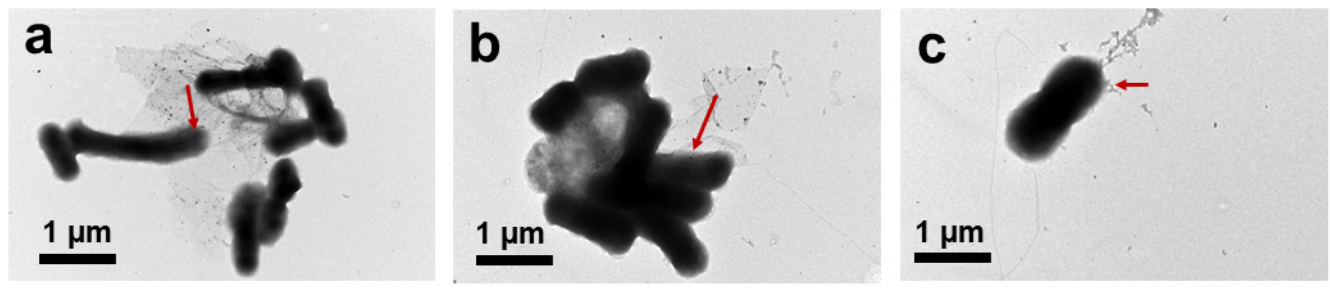

Figure 13. TEM images of E. coli after treatment with $>1 \mu \mathrm{m}(\mathbf{a}), \sim 1 \mu \mathrm{m}(\mathbf{b})$ and $\sim 100 \mathrm{~nm}(\mathbf{c}) \mathrm{GO}-\mathrm{Ag}$ NPs for $1 \mathrm{~h}$ incubation. Red arrow indicated for silver nanoparticles (Ag NPs) penetration into E. coli.

Another reason for the difference in antibacterial activity may relate to the amount of $\mathrm{Ag}^{+}$released from small and large GO-Ag NPs. According to the ICP-OES results (Figure 6), the initial Ag content from the $>1 \mu \mathrm{m} \mathrm{GO}-\mathrm{Ag}$ NPs was higher than that from the $\sim 100 \mathrm{~nm}$ GO-Ag NPs. Moreover, the release rate of $\mathrm{Ag}^{+}$from the $>1 \mu \mathrm{m} \mathrm{GO}-\mathrm{Ag}$ NPs was significantly higher than that in $\sim 100 \mathrm{~nm}$ GO-Ag NPs. Similar finding was also reported in the literature [48]. The release of nanoparticle ions generates an electrochemical potential and increases over time; these ions bind with thiol groups in the phospholipid membrane and inactive bacterial proteins, resulting in bacterial death [49]. On the other hand, released $\mathrm{Ag}^{+}$penetrates the bacterial cell walls, results in structural changes, and damages the inner and outer bacterial structure [50].

The third reason is the high ROS production induced by $>1 \mu \mathrm{m}$ GO-Ag NPs. ROS damage membrane-bound enzyme function, deactivate cellular enzymes and DNA, and inhibit the development of bacterial colonies. Moreover, the FTIR spectra in Figure 11 of both 100 nm and $>1 \mu \mathrm{m}$ GO-Ag NPs exhibit intense peaks attributed to disulfide (S-S) bond vibrations, possibly because the nanometal may disturb the boundary of the defense barrier of the bacterial membrane [51]. The interaction between GO support and aromatic molecules occurs through $\pi-\pi$ stacking. An interaction occurs between the polyaromatic domain and analytes on the GO surface, which works as a suitable platform for molecular trapping [52]. After treatment with GO, the bacterial membrane lost integrity as compared with the control E. coli (Figure 9). The GO functional groups, which bind with amino acids, have slightly changed. This phenomenon was indicated by a reduced intensity of $\mathrm{C}=\mathrm{O}$ groups when combined with $\mathrm{a}-\mathrm{PO}_{4}^{-3}$ group (secondary amino acid in E. coli membrane). Figure 14 summarizes the hypothesized mechanism of large GO-Ag NPs inactivating E. coli. In contrast, smaller GO-Ag NPs release fewer $\mathrm{Ag}^{+}$ions, resulting in few $\mathrm{Ag}^{+}$contact with the bacteria, low ROS generation and bactericidal effect. Therefore, the antibacterial activity of small GO-Ag NPs were proposed to be the disturbance of GO sheets and $\mathrm{Ag}^{+}$ion release, whereas that of larger GO-Ag NPs was proposed due to a combination of wrapping by GO sheets, significant $\mathrm{Ag}^{+}$ion release and $\mathrm{ROS}$ production. 


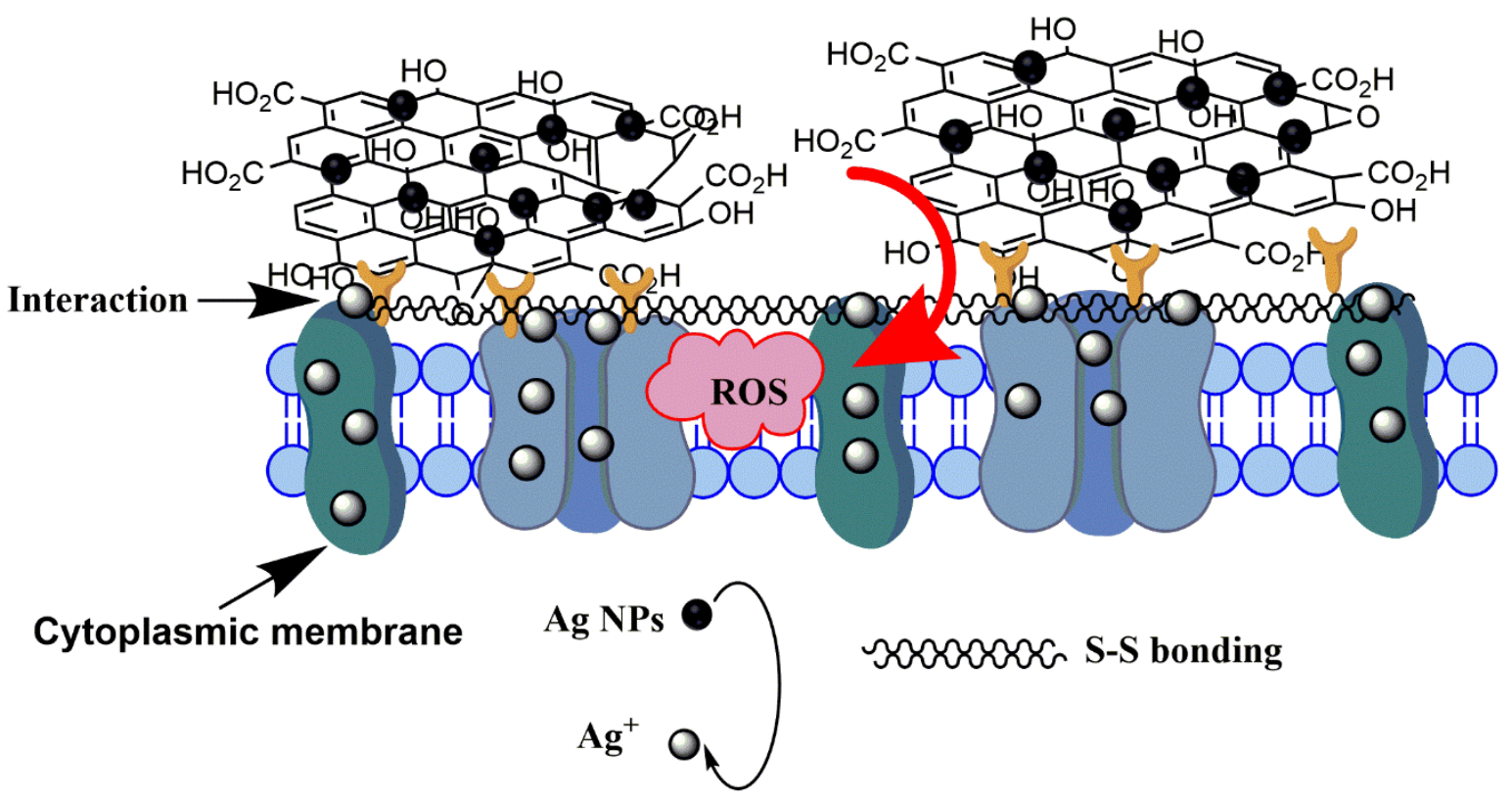

Figure 14. Proposed mechanism of interaction between E. coli and large GO-Ag NPs.

Table 2 summarizes the method, size category and mechanism of action from selected articles. Previous studies reported multiple mechanisms of action, including physical and chemical effects. Our antibacterial results are in agreement with those studies $[14,15,18]$. Large GO sheets exhibit more antibacterial effects than the small GO sheets in the solution phase. We proposed that, in addition to the trapping mechanism, the intensity of FTIR spectral peaks attributed to $-\mathrm{COOH}$ and $-\mathrm{PO}_{4}^{-3}$ reactive groups and disulfide bonding (S-S) was higher in the spectra of large GO than that in the spectra of small GO. More investigations on gram-positive bacteria using GO and GO-Ag NP composites is suggested. 
Table 2. A summary of GO's various size-dependent antibacterial effects.

\begin{tabular}{|c|c|c|c|c|c|}
\hline Lateral Size & Preparation & $\begin{array}{l}\text { Characterization } \\
\text { of Size }\end{array}$ & Bacteria/Cell Inactivation Results & Mechanism of Action (Finding) & Reference \\
\hline $\begin{array}{l}0,753,0.127,0.065,0.035 \\
\quad 0.013,0.01 \mu \mathrm{m}^{2}\end{array}$ & $\begin{array}{l}\text { Preparation for } 0,10,30, \\
50,120 \text { and } 240 \mathrm{~min}\end{array}$ & AFM & $\begin{array}{l}\text { - Largest size GO showed } 99 \% \\
\text { inhibition rate whereas around } 56.2 \% \\
\text { for smallest size GO. }\end{array}$ & - $\quad$ Large GO can cover E. coli & [14] \\
\hline $\begin{array}{c}0.65,0.29,0.1 \text { and } 0.01 \\
\mu \mathrm{m}^{2}\end{array}$ & $\begin{array}{l}\text { Preparation for } 0,1,10 \\
\text { and } 120 \mathrm{~min}\end{array}$ & SEM & $\begin{array}{l}\text { - Dispersion phase: larger } \\
\text { >smaller size. } \\
\text { - Coated membrane phase: smaller > } \\
\text { larger size }\end{array}$ & $\begin{array}{l}\text { Dispersion phase: E. coli was } \\
\text { inactive when entrapped by } \\
\text { large GO } \\
\text { Membrane phase: Small GO } \\
\text { caused loss of GSH than } \\
\text { large GO. }\end{array}$ & [18] \\
\hline $\begin{array}{l}\text { GQD }(<15 \mathrm{~nm}) \text {, SGO } \\
(50-200 \mathrm{~nm}) \text { and LGO } \\
\quad(0.5-3 \mu \mathrm{m})\end{array}$ & Commercial products & AFM & $\begin{array}{l}\text { - } \quad \text { E. coli: } \text { LGO reduced viability by } 30 \% \\
>\text { SGO }(5.3 \%)>\text { GQD (no effect) } \\
\text { - } \quad \text { Murine cell: LGO reduced viability > } \\
\text { SGO > GQD }\end{array}$ & $\begin{array}{l}\text { - Destruction by LGO and SGO } \\
\text { but not by GQD. }\end{array}$ & [15] \\
\hline $\begin{array}{l}\mathrm{SGO}(30 \mathrm{~nm}), \mathrm{MGO}(300 \\
\mathrm{nm}) \text { and LGO }(1 \mu \mathrm{m})\end{array}$ & $\begin{array}{l}\text { Synthesis using Hummer } \\
\text { method from different } \\
\text { size of graphites }\end{array}$ & $\begin{array}{l}\text { AFM } \\
\text { and DLS }\end{array}$ & $\begin{array}{ll}\text { - } & \text { SGO }(78 \%)>\text { LGO }(76.4 \%)>\text { MGO } \\
& (69.1 \%) \text { for bacterial strains (Tox2) } \\
\text { - } & \text { Toxicity effect on zebrafish was LGO } \\
& >\text { MGO }>\text { SGO }\end{array}$ & $\begin{array}{l}\text { - } \quad \text { ROS production by bacteria } \\
\text { strain was } \mathrm{LGO}<\mathrm{MGO}<\mathrm{SGO} \text {. }\end{array}$ & [17] \\
\hline $\begin{array}{l}\sim 100 \mathrm{~nm}, 100 \mathrm{~nm} \text { to } 1 \mu \mathrm{m}, \\
\sim 1 \mu \mathrm{m} \text { and }>1 \mu \mathrm{m}\end{array}$ & $\begin{array}{l}\text { Preparation for } 0,30,60 \\
\text { and } 120 \mathrm{~min}\end{array}$ & $\begin{array}{l}\text { TEM and } \\
\text { DLS results }\end{array}$ & $\begin{array}{l}\text { - } \quad 17.8 \%, 30.1 \%, 41.8 \% \text { and } 47.9 \% \text { for } \\
\sim 100 \mathrm{~nm}, 100 \mathrm{~nm} \text { to } 1 \mu \mathrm{m}, \sim 1 \mu \mathrm{m} \text { and } \\
>1 \mu \mathrm{m} \mathrm{GO} \\
27.6 \%, 80.6 \%, 83.2 \% \text { and } 88.6 \% \text { for } \sim \\
\text { - } 100 \mathrm{~nm}, 100 \mathrm{~nm}-1 \mu \mathrm{m}, \sim 1 \mu \mathrm{m} \text { and }>1 \\
\mu \mathrm{m} \mathrm{GO}-\mathrm{Ag} \mathrm{NPs}\end{array}$ & $\begin{array}{ll}\text { - } & \text { LGO entrap E. coli. } \\
\text { - } & \text { LGO-Ag exhibited more Ag+ } \\
& \text { release than U-SGO-Ag } \\
\text { - } & \text { LGO induce more } \mathrm{ROS}\end{array}$ & This study \\
\hline
\end{tabular}

Notes: GQD: graphene quantum dots; LGO: large GO; MGO: medium GO; SGO: small GO; GSH: glutathione; SEM: scanning electron microscope; AFM: atomic force microscopy. 


\section{Conclusions}

In summary, probe sonication was used to fabricate GO and GO-Ag NPs with controllable sizes. Both quantitative and qualitative antibacterial activities were examined by time-dependent antibacterial activity and live/dead bacterial assays against $E$. coli. The results showed that $>1 \mu \mathrm{m}$ GO had a greater antibacterial effect than the $\sim 100 \mathrm{~nm}$ GO. As seen in the TEM images, the E. coli were wrapped by large GO sheets, whereas the small GO caused a disturbance of the E. coli cells without totally isolating them from the nutrition medium. The larger GO-Ag NPs showed higher antibacterial activity than the smaller GO-Ag NPs. Mechanisms of the antibacterial behavior of large GO-Ag NPs were proposed based on chemical and physical properties. Firstly, large GO sheets physically wrap and inhibit the growth of E. coli. Secondly, $\mathrm{Ag}^{+}$is released rapidly accumulating at the membrane surface and then penetrating into the cell interior. ROS production, which correlates with redox reactions, results in more cell death. In contrast, the $\sim 100 \mathrm{~nm}$ GO-Ag NPs showed less bactericidal effects due to low ROS production and lower $\mathrm{Ag}^{+}$release. This potential finding provides the size effect role, but also creates a foundation for a number of further biomaterial applications. This work also demonstrates valuable current insight and excitement to conquer new areas, such as waste water treatment, bacteria resistance or prevent biofilm formation.

Supplementary Materials: The following are available online at http://www.mdpi.com/2079-4991/10/6/1207/s1, Figure S1: FTIR (a) and XRD (b) analysis of GO, Figure S2: FTIR (a) and XRD (b) analysis of GO-Ag NPs, Figure S3. Antibacterial activities of GO during $13 \mathrm{~h}$ observation (a) and GO-Ag NPs (b) during $4 \mathrm{~h}$ observation.

Author Contributions: S.J.L. planned the research work and revised the full paper; T.T.T.V. wrote the paper, conducted the data and revised the paper; S.R.K. contributed to the paper writing, discussion, and manuscript revision; Y.-T.H. suggested the goal and planned antibacterial test; D.W.C. suggested the research goals and helped in the funding application for this project; Y.-K.L. provided the bacteria resources and gave the suggestions. All authors have read and agreed to the published version of the manuscript.

Funding: The work was supported by grant CMRP2G0423 from Chang Gung Memorial Hospital.

Acknowledgments: The authors wish to thank the financial support from Chang Gung Memorial Hospital funding numbers CMRPG2G0423.

Conflicts of Interest: The authors declare no conflict of interest.

\section{References}

1. Ayukekbong, J.A.; Ntemgwa, M.; Atabe, A.N. The threat of antimicrobial resistance in developing countries: Causes and control strategies. Antimicrob. Resist. Infect. Control 2017, 6, 47. [CrossRef] [PubMed]

2. Martí, M.; Frígols, B.; Serrano-Aroca, A. Antimicrobial Characterization of Advanced Materials for Bioengineering Applications. J Vis. Exp. 2018, 138, 57710. [CrossRef] [PubMed]

3. Matharu, R.K.; Ciric, L.; Edirisinghe, M. Nanocomposites: Suitable alternatives as antimicrobial agents. Nanotechnology 2018, 29, 282001. [CrossRef]

4. Mohammed, M.K.A.; Ahmed, D.S.; Mohammad, M.R. Studying antimicrobial activity of carbon nanotubes decorated with metal-doped ZnO hybrid materials. Mater. Res. Express 2019, 6, 055404. [CrossRef]

5. Gold, K.; Slay, B.; Knackstedt, M.; Gaharwar, A.K. Antimicrobial Activity of Metal and Metal-Oxide Based Nanoparticles. Adv. Ther. 2018, 1, 1700033. [CrossRef]

6. Novoselov, K.S.; Geim, A.K.; Morozov, S.V.; Jiang, D.; Zhang, Y.; Dubonos, S.V.; Grigorieva, I.V.; Firsov, A.A. Electric Field Effect in Atomically Thin Carbon Films. Science 2004, 306, 666-669. [CrossRef] [PubMed]

7. Stankovich, S.; Dikin, D.A.; Dommett, G.H.B.; Kohlhaas, K.M.; Zimney, E.J.; Stach, E.A.; Piner, R.D.; Nguyen, S.T.; Ruoff, R.S. Graphene-based composite materials. Nature 2006, 442, 282-286. [CrossRef]

8. Karahan, H.E.; Wang, Y.; Li, W.; Liu, F.; Wang, L.; Sui, X.; Riaz, M.A.; Chen, Y. Antimicrobial graphene materials: The interplay of complex materials characteristics and competing mechanisms. Biomater. Sci. 2018, 6, 766-773. [CrossRef]

9. Mangadlao, J.D.; Santos, C.M.; Felipe, M.J.L.; de Leon, A.C.C.; Rodrigues, D.F.; Advincula, R.C. On the antibacterial mechanism of graphene oxide (GO) Langmuir-Blodgett films. Chem. Commun. 2015, 51, 2886-2889. [CrossRef] [PubMed] 
10. Zou, F.; Zhou, H.; Jeong, D.; Kwon, J.; Eom, S.; Park, T.J.; Hong, S.W.; Lee, J. Wrinkled Surface-Mediated Antibacterial Activity of Graphene Oxide Nanosheets. ACS Appl. Mater. Interfaces 2016, 9. [CrossRef] [PubMed]

11. Liu, S.; Zeng, T.H.; Hofmann, M.; Burcombe, E.; Wei, J.; Jiang, R.; Kong, J.; Chen, Y. Antibacterial Activity of Graphite, Graphite Oxide, Graphene Oxide, and Reduced Graphene Oxide: Membrane and Oxidative Stress. Acs Nano 2011, 5, 6971-6980. [CrossRef] [PubMed]

12. Kurantowicz, N.; Sawosz, E.; Jaworski, S.; Kutwin, M.; Strojny, B.; Wierzbicki, M.; Szeliga, J.; Hotowy, A.; Lipińska, L.; Koziński, R.; et al. Interaction of graphene family materials with Listeria monocytogenes and Salmonella enterica. Nanoscale Res. Lett. 2015, 10, 23. [CrossRef] [PubMed]

13. Ji, H.; Sun, H.; Qu, X. Antibacterial applications of graphene-based nanomaterials: Recent achievements and challenges. Adv. Drug Deliv. Rev. 2016, 105, 176-189. [CrossRef] [PubMed]

14. Liu, S.; Hu, M.; Zeng, T.H.; Wu, R.; Jiang, R.; Wei, J.; Wang, L.; Kong, J.; Chen, Y. Lateral Dimension-Dependent Antibacterial Activity of Graphene Oxide Sheets. Langmuir 2012, 28, 12364-12372. [CrossRef]

15. Zhao, L.; Duan, G.; Yang, Z.; Weber, J.; Liu, X.; Lu, S.; Meng, X.; Xu, J. Particle Size-Dependent Antibacterial Activity and Murine Cell Cytotoxicity Induced by Graphene Oxide Nanomaterials. J. Nanomater. 2016, 2016, 1-9. [CrossRef]

16. Faria, A.F.; Perreault, F.; Elimelech, M. Elucidating the Role of Oxidative Debris in the Antimicrobial Properties of Graphene Oxide. Acs Appl. Nano Mater. 2018, 1, 1164-1174. [CrossRef]

17. Jia, P.-P.; Sun, T.; Junaid, M.; Yang, L.; Ma, Y.-B.; Cui, Z.-S.; Wei, D.-P.; Shi, H.-F.; Pei, D.-S. Nanotoxicity of different sizes of graphene $(\mathrm{G})$ and graphene oxide (GO) in vitro and in vivo. Environ. Pollut. 2019, 247, 595-606. [CrossRef]

18. Perreault, F.; de Faria, A.F.; Nejati, S.; Elimelech, M. Antimicrobial Properties of Graphene Oxide Nanosheets: Why Size Matters. Acs Nano 2015, 9, 7226-7236. [CrossRef]

19. Dallavalle, M.; Calvaresi, M.; Bottoni, A.; Melle-Franco, M.; Zerbetto, F. Graphene Can Wreak Havoc with Cell Membranes. Acs Appl. Mater. Interfaces 2015, 7, 4406-4414. [CrossRef]

20. Kumar, P.; Huo, P.; Zhang, R.; Liu, B. Antibacterial Properties of Graphene-Based Nanomaterials. Nanomaterials 2019, 9, 737. [CrossRef]

21. Jiang, L.; Su, C.; Ye, S.; Wu, J.; Zhu, Z.; Wen, Y.; Zhang, R.; Shao, W. Synergistic antibacterial effect of tetracycline hydrochloride loaded functionalized graphene oxide nanostructures. Nanotechnology 2018, 29, 505102. [CrossRef] [PubMed]

22. Wang, H.; Liu, J.; Wu, X.; Tong, Z.; Deng, Z. Tailor-made Au@Ag core-shell nanoparticle 2D arrays on protein-coated graphene oxide with assembly enhanced antibacterial activity. Nanotechnology 2013, 24, 205102. [CrossRef] [PubMed]

23. Le Ouay, B.; Stellacci, F. Antibacterial activity of silver nanoparticles: A surface science insight. Nano Today 2015, 10, 339-354. [CrossRef]

24. Vi, T.T.T.; Rajesh Kumar, S.; Rout, B.; Liu, C.-H.; Wong, C.-B.; Chang, C.-W.; Chen, C.-H.; Chen, D.W.; Lue, S.J. The Preparation of Graphene Oxide-Silver Nanocomposites: The Effect of Silver Loads on Gram-Positive and Gram-Negative Antibacterial Activities. Nanomaterials 2018, 8, 163. [CrossRef] [PubMed]

25. Truong, V.; Kumar, S.R.; Pang, J.S.; Liu, Y.K.; Chen, D.W.; Lue, S.J. Synergistic Antibacterial Activity of Silver-Loaded Graphene Oxide towards Staphylococcus Aureus and Escherichia Coli. Nanomaterials 2020, 10, 366. [CrossRef]

26. Cobos, M.; De-La-Pinta, I.; Quindós, G.; Fernández, M.J.; Fernández, M.D. Graphene Oxide-Silver Nanoparticle Nanohybrids: Synthesis, Characterization, and Antimicrobial Properties. Nanomaterials 2020, 10, 376. [CrossRef]

27. Bao, Q.; Zhang, D.; Qi, P. Synthesis and characterization of silver nanoparticle and graphene oxide nanosheet composites as a bactericidal agent for water disinfection. J. Colloid Interface Sci. 2011, 360, 463-470. [CrossRef]

28. De Faria, A.F.; Martinez, D.S.T.; Meira, S.M.M.; de Moraes, A.C.M.; Brandelli, A.; Filho, A.G.S.; Alves, O.L. Anti-adhesion and antibacterial activity of silver nanoparticles supported on graphene oxide sheets. Colloids Surf. B: Biointerfaces 2014, 113, 115-124. [CrossRef]

29. Baskoro, F.; Wong, C.-B.; Kumar, S.R.; Chang, C.-W.; Chen, C.-H.; Chen, D.W.; Lue, S.J. Graphene oxide-cation interaction: Inter-layer spacing and zeta potential changes in response to various salt solutions. J. Membr. Sci. 2018, 554, 253-263. [CrossRef] 
30. Gurunathan, S.; Arsalan Iqbal, M.; Qasim, M.; Park, C.H.; Yoo, H.; Hwang, J.H.; Uhm, S.J.; Song, H.; Park, C.; Do, J.T.; et al. Evaluation of Graphene Oxide Induced Cellular Toxicity and Transcriptome Analysis in Human Embryonic Kidney Cells. Nanomaterials 2019, 9, 969. [CrossRef]

31. Charalampopoulos, T.T. Morphology and dynamics of agglomerated particulates in combustion systems using light scattering techniques. Prog. Energy Combust. Sci. 1992, 18, 13-45. [CrossRef]

32. Eaton, P.; Quaresma, P.; Soares, C.; Neves, C.; de Almeida, M.P.; Pereira, E.; West, P. A direct comparison of experimental methods to measure dimensions of synthetic nanoparticles. Ultramicroscopy 2017, 182, 179-190. [CrossRef] [PubMed]

33. Tao, H.; Zhang, Y.; Gao, Y.; Sun, Z.; Yan, C.; Texter, J. Scalable exfoliation and dispersion of two-dimensional materials - an update. Phys. Chem. Chem. Phys. 2017, 19, 921-960. [CrossRef]

34. He, J.; Zhu, X.; Qi, Z.; Wang, C.; Mao, X.; Zhu, C.; He, Z.; Li, M.; Tang, Z. Killing Dental Pathogens Using Antibacterial Graphene Oxide. Acs Appl. Mater. Interfaces 2015, 7, 5605-5611. [CrossRef] [PubMed]

35. Soroush, A.; Ma, W.; Silvino, Y.; Rahaman, M. Surface Modification of Thin Film Composite Forward Osmosis Membrane by Silver-Decorated Graphene-Oxide Nanosheets. Environ. Sci. Nano. 2015, 2, $395-405$. [CrossRef]

36. Çiplak, Z.; Yildiz, N.; Çalimli, A. Investigation of Graphene/Ag Nanocomposites Synthesis Parameters for Two Different Synthesis Methods. Fuller. Nanotub. Carbon Nanostructures 2014, 23, 361-370. [CrossRef]

37. Kavinkumar, T.; Varunkumar, K.; Ravikumar, V.; Manivannan, S. Anticancer activity of graphene oxide-reduced graphene oxide-silver nanoparticle composites. J. Colloid Interface Sci. 2017, 505, 1125-1133. [CrossRef]

38. Hui, K.S.; Hui, K.N.; Dinh, D.A.; Tsang, C.H.; Cho, Y.R.; Zhou, W.; Hong, X.; Chun, H.-H. Green synthesis of dimension-controlled silver nanoparticle-graphene oxide with in situ ultrasonication. Acta Mater. 2014, 64, 326-332. [CrossRef]

39. Xu, C.; Wang, X.; Zhu, J. Graphene-Metal Particle Nanocomposites. J. Phys. Chem. C 2008, 112, 19841-19845. [CrossRef]

40. Zhao, J.; Liu, Z.; Qin, Y.; Hu, W. Fabrication of Co3O4/graphene oxide composites using supercritical fluid and their catalytic application for the decomposition of ammonium perchlorate. CrystEngComm 2014, 16, 2001. [CrossRef]

41. Romero-Vargas Castrillón, S.; Perreault, F.; de Faria, A.F.; Elimelech, M. Interaction of Graphene Oxide with Bacterial Cell Membranes: Insights from Force Spectroscopy. Environ. Sci. Technol. Lett. 2015, 2, 112-117. [CrossRef]

42. Park, D.; Yun, Y.S.; Park, J.M. Studies on hexavalent chromium biosorption by chemically-treated biomass of Ecklonia sp. Chemosphere 2005, 60, 1356-1364. [CrossRef] [PubMed]

43. Maas, M.; Perold, W.; Dicks, L. Biosensors for the detection of Escherichia coli. Water S.A 2017, 43, 707-721. [CrossRef]

44. Inaba, K.; Ito, K. Structure and mechanisms of the DsbB-DsbA disulfide bond generation machine. Biochim. Et Biophys. Acta (Bba) Mol. Cell Res. 2008, 1783, 520-529. [CrossRef]

45. Efremova, L.V.; Vasilchenko, A.S.; Rakov, E.G.; Deryabin, D.G. Toxicity of Graphene Shells, Graphene Oxide, and Graphene Oxide Paper Evaluated with Escherichia coli Biotests. Biomed Res. Int. 2015, 2015, 869361. [CrossRef]

46. Camesano, T.; Logan, B. Probing Bacterial Electrosteric Interactions Using Atomic Force Microscopy. Environ. Sci. Technol. 2000, 34, 16. [CrossRef]

47. Quintelas, C.; Rocha, Z.; Silva, B.; Fonseca, B.; Figueiredo, H.; Tavares, T. Removal of Cd(II), Cr(VI), Fe(III) and $\mathrm{Ni}$ (II) from aqueous solutions by an E. coli biofilm supported on kaolin. Chem. Eng. J. 2009, 149, 319-324. [CrossRef]

48. Sondi, I.; Salopek-Sondi, B. Silver nanoparticles as antimicrobial agent: A case study on E. coli as a model for Gram-negative bacteria. J. Colloid Interface Sci. 2004, 275, 177-182. [CrossRef] [PubMed]

49. Tamayo, L.A.; Zapata, P.A.; Vejar, N.D.; Azócar, M.I.; Gulppi, M.A.; Zhou, X.; Thompson, G.E.; Rabagliati, F.M.; Páez, M.A. Release of silver and copper nanoparticles from polyethylene nanocomposites and their penetration into Listeria monocytogenes. Mater. Sci. Eng. C 2014, 40, 24-31. [CrossRef] [PubMed]

50. Jung, W.K.; Koo, H.C.; Kim, K.W.; Shin, S.; Kim, S.H.; Park, Y.H. Antibacterial Activity and Mechanism of Action of the Silver Ion in Staphylococcus aureus and Escherichia coli. Appl. Environ. Microbiol. 2008, 74, 2171. [CrossRef] 
51. Garip, S.; Bozoglu, F.; Severcan, F. Differentiation of Mesophilic and Thermophilic Bacteria with Fourier Transform Infrared Spectroscopy. Appl. Spectrosc. 2007, 61, 186-192. [CrossRef] [PubMed]

52. Nanda, S.S.; Yi, D.K.; Kim, K. Study of antibacterial mechanism of graphene oxide using Raman spectroscopy. Sci. Rep. 2016, 6, 28443. [CrossRef] [PubMed]

(c) (

(C) 2020 by the authors. Licensee MDPI, Basel, Switzerland. This article is an open access article distributed under the terms and conditions of the Creative Commons Attribution (CC BY) license (http://creativecommons.org/licenses/by/4.0/). 